\title{
A modellek elsősorban eszközök
}

\section{Costas Azariadis - Riddles and Models: A Review Essay on Michel De Vroey's A History of Macroeconomics from Keynes to Lucas and Beyond}

Michel De Vroey a 2016-ban megjelent A History of Macroeconomics form Keynes to Lucas and Beyond címü könyvében a közgazdaságtan eddig megszületett makroökonómiai elméleteinek összefoglalására tesz ambiciózus kísérletet, sorra véve a tudományág sikereit és kudarcait John M. Keynestől kezdve többek között Robert E. Lucason és Edward C. Prescotton át egészen a 20. század utolsó évtizedében teret nyerö új keynesi modellekig. Erről a könyvröl nyújt Costas Azariadis áttekintő összefoglalót, amelyben kiemeli a makroökonómusok közel egy évszázad alatt megválaszolt, illetve megválaszolatlanul maradt kérdéseit. A makroökonómia John Maynard Keynes munkásságával vált a közgazdaságtan jól megkülönböztethető részterületévé az 1930-as évek végén. Keynest és a kortárs közgazdászokat elsősorban a Nagy Válság okán kialakult tömeges munkanélküliség miértjének és gyógyírjának felderítése ösztönözte a nemzetgazdaság müködésének aprólékos vizsgálatára. A 20. század előrehaladtával azonban a makroökonómusok figyelme a mély válságok és a tömeges munkanélküliség problémájáról többek között az üzleti ciklusokra, az eszközbuborékokra, az innováció rövid távú hatásaira, az intézmények szerepére és a jövedelmi, illetve vagyoni egyenlőtlenségekre terelődött. A század végére az egyre szofisztikáltabb gazdaságpolitikai eszköztárnak köszönhetően az üzleti ciklusok volatilitása nagyban csökkent, ezen folyamatban pedig a könyv szerzője szerint Lucas és az ő nyomán megjelenő DSGE (dynamic stochastic general equilibrium) modellek jelentettek fordulópontot.

\section{A makroökonómiai modellek 20. századi fejlődése}

De Vroey alapvetően Keynest és Lucast tartja a 20. századi makroökonómia főszereplőinek, az őket követő időszakot pedig megítélése szerint a két irányzat összehangolására tett kísérletek határozzák meg. Keynes munkásságából három kérdést emel ki: i) a frikciós és az önkéntes munkanélküliség megkülönböztetésének problémáját, ii) a növekvő bizonytalanság szerepét a beruházási döntésekben, iii) továbbá egy olyan elméleti keret megalkotását, amelyben a tökéletes verseny során kialakuló árak nem ragadósak, azonban a gazdasági szereplők rövid távú várakozásai torzítottak. Keynes statikus, periódusról periódusra egyensúlytalanságot produkáló elméleti keretének a hosszú távú walrasi általános egyensúllyal való összehangolására több kísérletet is tettek a 20. század során, azonban ezen kísérleteket a könyv szerzője szerint Axel Leijonhufvud aforizmája foglalja össze a legtalálóbban: „Keynes és Walras összeférhetetlen ágyasok voltak."

Az 1960-as években kerültek előtérbe Phillips megfigyelései a munkanélküliségi ráta és az infláció közti negatív kapcsolatról. Milton Friedman kritikája szerint, amennyiben a gazdasági szereplők inflációs várakozásai fokozatosan alkalmazkodnak a valós inflációhoz, úgy nincs trade-off a munkanélküliség és az infláció között. Friedman nevéhez köthető továbbá a munkanélküliség természetes rátájának fogalma is. Ehhez az elméleti folyamathoz kapcsolódik Edmund Phelps munkássága az üres álláshelyek és a munkanélküliség kapcsolatát illetően. Azariadis álláspontja szerint ezen elméletek értelme csupán annyi, hogy bebizonyosult, hogy a monetáris politika kevés a munkaerőpiaci problémák kezelésére.

Visszatérve a könyvhöz: a '70-es években megfogalmazott Lucas kritika a makroökonómia azon könnyelmüségét bírálta, hogy nem vette figyelembe a gazdaságpolitikai lépések hatását a gazdasági 
szereplők magatartására, és beérte az aggregált historikus adatokra való támaszkodással. Ettől kezdve a makroökonómusok mindinkább arra törekedtek, hogy mikroökonómiai alapokra építsék fel elméleteiket. Részben ez vezetett el a DSGE modellekhez, és ezen modellcsalád részeként az RBC modellek megjelenéséhez is, melyek egy tökéletes versenyző piac reprezentatív fogyasztójának magatartásából indulnak ki. Az RBC modellek a reálgazdaságból kiinduló sokkokkal magyarázzák az üzleti ciklusokat, ezen modellek nyomán került előtérbe a teljes tényezőtermelékenység (TFP) meghatározó szerepe a rövid távú folyamatokban. Bár a TFP megfoghatatlansága és absztraktsága még ma is kihívást jelent a makroökonómia számára, az RBC modellek (melyek elsősorban Kydland és Prescott nevéhez füződnek) kielégítő választ tudtak adni a rövid távú gazdasági fluktuációkra. Ugyanakkor ez a keretrendszer nem tud irányt mutatni a gazdaságpolitika számára - a monetáris politikának szerepet sem ad -, mivel az elmélet szerint a gazdasági kilengések minden esetben társadalmilag optimális pontba juttatják a gazdaságot, azaz a gazdaságpolitika akkor jár el helyesen, ha nem avatkozik be a ciklusokba.

Többek között az RBC modellek gazdaságpolitikai tanácsadásra vonatkozó alkalmatlansága miatt jelentek meg a '90-es évek végén az új keynesi modellek, amelyek keretein belül a jóléti tételek ${ }^{1}$ nem valósulnak meg, így a piacok sem tisztulnak ki. Kétségtelen, hogy az új keynesi modellkeret el tudja helyezni a monetáris politikát, mert egyik alapvető feltételezése az árragadósság, így a pénzsemlegesség biztosításának érdekében szükség van megfelelő monetáris politikára. Az RBC modellekhez hasonlóan az új keynesi modellek is jól képesek leírni az USA második világháború utáni gazdaságának empirikus adatait, azonban Azariadis szerint ez a keret logikailag kevésbé koherens, egyes feltevések - például az árragadósság - miértjének magyarázata hiányos és/vagy zavaros.

\section{A 21. század három alapvető modellkerete}

A recenzió kitér arra, hogy a 21. századra három modellkeret áll a makroökonómusok rendelkezésére. Ezek a modellkeretek alapfeltevéseikben különböznek, és bár tökéletlenül, de hasonló hatékonysággal képesek leírni a gazdasági mutatók időbeli ingadozásait. Ez a három modellkeret nem csupán alapfeltevéseiben, de mechanizmusában, a jóléti tételekhez való viszonyulásában és a különböző külső sokkokra adott válaszában is eltér.

A neoklasszikus gyökerekkel rendelkező RA (representative/stand-in household) struktúra keretében felépített modellek egyszerü döntési helyzetekre alapoznak, ahol a fogyasztók fogyasztási termékeket és szabadidőt fogyasztanak, teljes informáltság és homogenitás jellemzi őket, optimális döntéseiket pedig az életpálya jövedelmük által meghatározott költségvetési korlát mellett hozzák meg. Termelői oldalon a tőke, a munka és a technológia határozza meg a konstans mérethozadékkal és zéró profittal működő vállalatok kibocsátási szintjét. A modell keretein belül a sokkok gyorsan lecsengenek, a gazdaság pedig rövid idő alatt visszatér egy jól definiált egyensúlyba. Az ezt a keretet érintő legfőbb kritika egyrészt az, hogy nem kínál alternatívát a homogén gazdasági szereplőkkel szemben, miközben azok a valóságban heterogének, ami jelentősen árnyalja a döntési mechanizmusokat. Másrészt pedig a pénzsemlegesség, és végső soron a gazdaságpolitika feleslegessége jellemzi ezt a modellcsaládot, ami szintén nehezen feleltethető meg a valóságnak. Az utóbbi probléma okán az akadémiai életen kívül nem is tudtak elterjedni az ezen alapokra épülő modellek, az üzleti világ és a központi bankok nem nagyon tudják hasznosítani a gyakorlatban.

\footnotetext{
${ }^{1}$ Első jóléti tétel: bizonyos feltételek mellett minden versenyzői optimum egyben Pareto-optimum is.

Második jóléti tétel: bizonyos feltételek mellett minden Pareto-optimum előállítható versenyzői optimumként a kezdőkészletek reallokációjával.
} 
Az OLG (overlapping generations) modellstruktúrában jelentős szerepe van a generációk közötti erőforrásallokációnak, a gazdasági szereplők heterogenitásának, a várakozásoknak, illetve a bizonytalanságnak. Az OLG modellek figyelmüket a koordinációs kudarcokra fordítják, az ezek okán kialakuló gazdasági pánikok jólétpusztító hatásának elemzésére tesznek kísérletet, azonban a rövid és középtávú elemzésekre alkalmatlan modellezési keretben épülnek fel, a mindennapi üzleti ciklus problémákat nem tudják jól megragadni.

Az NK (new keynesian) modellkeretben a ragadós árak okán a piacok nem tisztulnak ki a gazdaságban, kibocsátási rés keletkezik, így tehát a piac „láthatatlan keze” itt valóban láthatatlanná és egyúttal irrelevánssá is válik. Ez a kibocsátási rés a rugalmas árak melletti potenciális kibocsátás és a ragadós árak melletti valós kibocsátás szintjének különbségét jelenti. A ragadós áraknak köszönhetően ez a modellcsalád egyértelmüen le tudja követni a nominális sokkok - például a kamatszint megváltozása - reálszektorra kiterjedő hatását, ennek segítségével pedig a monetáris szerv számára megfelelő beavatkozási stratégiát tud nyújtani, és a gazdaságpolitika képes kezelni a kibocsátási rés jelenségét. Azariadis itt is kitér a már korábban említett kritikára: az NK modellek belső logikai konzisztenciája sok ponton megkérdőjelezendő.

\section{A reál üzleti ciklusok paradigmái}

A 20. században különböző nézetek alakultak ki a reál üzleti ciklusokra vonatkozóan. A neoklasszikus közgazdászok úgy tekintenek ezekre a ciklusokra, mint a piac válaszaira a gazdasági fundamentumokban bekövetkezett változásokra, amit a gazdaságpolitika képtelen megfelelően kezelni. A keynesiánusok szerint a piac nem öngyógyuló, így a ciklusokat kontraciklikus gazdaságpolitikával kell kezelni. A monetaristák amellett érvelnek, hogy a pénz és a hitelek játszanak főszerepet az üzleti ciklusokban. A várakozásokat középpontba helyezö közgazdászok koordinációs kudarcként tekintenek a gazdaság rövid távú teljesítménybeli ingadozására, ami elkerülhető a gazdaságpolitika beavatkozásával, a várakozások megfelelő manipulálásával. Az intézményi közgazdászok a tulajdonjogok és a politikai intézményrendszer jellegzetességeivel magyarázzák a gazdasági mutatók volatilitását. Az ezen paradigmák közti összhang megteremtése egyelöre a makroökonómia megoldatlan feladata.

\section{Megválaszolatlanul maradt kérdések}

Azariadis elismeri, hogy a makroökonómia eszköztára mind mennyiségi, mind minőségi szempontból hatalmas fejlődésen ment keresztül a 20. században, illetve hangsúlyozza azt is, hogy az adatok mennyisége és minősége is folyamatosan javul. Felhívja a figyelmet azonban arra, hogy az üzleti ciklusok motorja, a TFP ma is rosszul definiált, absztrakt mutató, aminek a megfejtésében nem sokat haladt előre a makroökonómia. Bár a munkanélküliség átmeneti sokkjait Mortensen és Pissarides munkássága óta meglehetősen jól tudjuk modellezni, azonban a perzisztens munkanélküliség problémájára még ma sem tudunk adekvát választ adni. Azariadis továbbá azt is hangsúlyozza, hogy a tőzsdeárfolyamok és a kockázati prémiumok alakulása a mai napig leginkább misztérium a közgazdászok körében, illetve az üzleti sokkok jóléti hatásainak számszerü elemzésében is van hova fejlődni. Amellett érvel, hogy a DSGE modellek sikerességének feltétele, hogy választ találjanak az üzleti ciklusok nyomán kialakuló hosszú távú problémákra (buborékok, likviditási pánikok stb.), megértsék, pontosan mi hajtja az üzleti ciklusokat és a növekedést, illetve megküzdjenek azzal a kérdéssel, hogy a döntéshozók magatartása miként befolyásolja ezeket.

Azariadis recenziójának bevezető mondata ekképp szól: „A makroökonómia az 1930-as években vált jól megkülönböztethető részterületté John Maynard Keynes és kortársainak a tömeges munkanélküliség és a 
mély válságok okát és gyógyírját kereső vizsgálódásainak melléktermékeként."2 Nem arról van tehát szó, hogy Keynes egy új tudományág tudatos szülőatyja volna. Keynes arra a kérdésre kereste a választ, hogy miként számolható fel a munkanélküliség, illetve hogy miért nem volt igaza Marxnak, amikor azt állította, hogy a kapitalista rendszer, és azzal együtt a demokrácia sem éli túl a rendszer immanens, periodikus válságait. Jobban mondva talán inkább arra, hogy miként kerülhető el, hogy Marxnak igaza legyen. Keynes a politikai gazdaságtan müvelője volt, nem makroökonómus. Morálfilozófiai meggyőződései meghaladni kívánták Bentham utilitarizmusát [Kirschner, 2015], amellett érvelt, hogy a kapitalizmus problémái nem technikai, hanem erkölcsi jellegüek [Carabelli-Cedrini, 2018], és jól megalapozott filozófiai koncepcióra építette közgazdaságtanát [Davis, 1991].

Kétségtelen, hogy a közgazdaságtudomány makroökonómiai és makroökonometriai eszköztárának 20. századi fejlődése kívánatos és eredményes volt, azonban nem lehet eléggé hangsúlyozni a modellek eszköz voltát. A 20. század során a közgazdaságtudomány Benthaméhoz hasonló hibát követett el, mivel célként definiálta azt, ami csupán eszköze a célnak [Lónyai, 1981]. A makroökonómia önmagában képtelen választ adni olyan normatív kérdésekre, mint mi a reálkamatláb igazságos szintje. A makroökonómia az egyes gazdaságpolitikai döntések, reál vagy pénzügyi sokkok hatásmechanizmusáról tud képet adni, azonban politikai gazdaságtan nélkül modelljei éppoly üresek, mint a kis herceg által bírált rózsák ${ }^{3}$, melyek értéktől mentesek. Nem csoda tehát, hogy amíg önálló tudományként definiáljuk a makroökonómiát, nem találunk valódi választ a valódi kérdéseinkre.

Szabó Dorottya ${ }^{4}$

\section{Felhasznált irodalom:}

Azariadis, C. (2018): Riddles and Models: A Review Essay on Michel De Vroey's A History of Macroeconomics form Keynes to Lucas and Beyond, Journal of Economic Literature, 56(4), p. 1538-1576

De Vroey, M. (2016): A History of Macroeconomics from Keynes to Lucas and Beyond, Cambirdge University Press

Kirshner, J. (2015): Keynes's Early Beliefs and Why They Still Matter, Challenge, 58(5), pp. 398-412.

Carabelli, A. M.-Cedrini, M. A. (2018): Great Expectations and Final Delusion - Keynes and the Ultimate Values of Capitalism, Cambridge Journal of Economics, Vol. 42, Issue 5, pp. 1183-1204

Davis, J. B. (1991): Keynes's critiques of Moore: philosophical foundations of Kenyes's economics, Cambridge Journal of Economics, 15(1), 61-77.

Lónyai M. (1981): Tények és értékek - A modern angolszász etika irodalmából, Budapest, Gondolat Kiadó

\footnotetext{
2 „Macroeconomics became a distinct field in the 1930s as a byproduct of inquiries by John Maynard Keynes and some contemporaries into the causes of, and cures for, mass unepmloyment and great contractions".

${ }^{3}$ Utalás Antoine de Saint-Exupéry: A kis herceg címü könyvére.

${ }^{4}$ egyetemi hallgató, Budapesti Corvinus Egyetem

DOI: 10.14267/RETP2021.01.18
} 